TITLE:

\title{
ANNOTATED CHECKLIST OF THE FISHES OF MIYAKE-JIMA, JAPAN. I. POMACENTRIDAE, CHAETODONTIDAE AND POMACANTHIDAE
}

\section{$\operatorname{AUTHOR}(S)$ :}

Shepard, J. W.; Moyer, J. T.

\section{CITATION:}

Shepard, J. W....[et al]. ANNOTATED CHECKLIST OF THE FISHES OF MIYAKE-JIMA, JAPAN. I. POMACENTRIDAE, CHAETODONTIDAE AND POMACANTHIDAE. PUBLICATIONS OF THE SETO MARINE BIOLOGICAL LABORATORY 1980, 25(1-4): 227-241

\section{ISSUE DATE:}

1980-02-29

URL:

http://hdl.handle.net/2433/175983

RIGHT: 


\title{
ANNOTATED GHEGKLIST OF THE FISHES OF MIYAKE-JIMA, JAPAN. I. POMAGENTRIDAE, GHAETODONTIDAE AND POMAGANTHIDAE1)
}

\author{
J. W. SHEPARD ${ }^{2)}$ and J. T. MOYER ${ }^{3)}$
}

With Text-figures 1-2, Table 1 and Plates I-II

\section{Introduction}

Miyake-jima $\left(34^{\circ} 05^{\prime} \mathrm{N}, 139^{\circ} 30^{\prime} \mathrm{E}\right)$ is one of the Izu Islands of Japan (Fig. 1). Situated $160 \mathrm{~km}$ south of Tokyo, the island is an active volcano that last erupted in 1962. It is part of the Shichito-Mariana orogenic zone which includes the Ogasawara (Bonin) and Volcano Islands, in addition to the Izu Islands. The island is nearly circular in shape, $8 \mathrm{~km}$ from north to south and $7.5 \mathrm{~km}$ from east to west, and is dominated by the $815 \mathrm{~m}$ slopes of Mt. Oyama.

Miyake-jima exhibits a lush subtropical flora of more than 500 varieties of plants (Honda, et al., 1958) and an abundant and interesting avifauna including several species and subspecies endemic to the Izu Islands (Moyer, 1957). Knowledge of the marine flora and fauna of the island remains largely limited to periodic reports of the Fishery Division of the Tokyo Metropolitan Government. Previous checklists of fishes appear to include only those of Kurata and Nagawa (1962) and Tamura (1974).

The island of Miyake-jima is of special interest to marine biologists due to its position on the northern fringe of the vast tropical Indo-West Pacific faunal region. Isolated colonies of reef-building corals are known from further north, but Miyake-jima exhibits what may be the most extensive patches of corals for corresponding latitudes anywhere in the world. The fish fauna of the volcanic reefs and coral patches of Miyake-jima is noteworthy for its representation of both tropical and temperate species.

The present paper is the first of a series of annotated checklists of the fishes of Miyake-jima resulting from research by staff members and visiting scientists at the Tanaka Memorial Biological Station, Miyake-jima. Included are listings of the families Pomacentridae, Chaetodontidae and Pomacanthidae. The apogonids of Miyake-jima were reported by Ida and Moyer (1974). Representatives of the Labridae, Pomacentridae, Lutjanidae, Pomacanthidae, and others have appeared in previous publications (Ida and Moyer, 1975; Moyer, 1975; Moyer and Ida, 1975;

1) Contribution No. 26, Tatsuo Tanaka Memorial Biological Station, and No. 136, University of Guam Marine Laboratory.

2) Marine Laboratory, University of Guam, P.O. Box EK, Agana, Guam 96910.

3) Tatsuo Tanaka Memorial Biological Station, Ako, Miyake-jima, Tokyo 100-12.

Publ. Seto Mar. Biol. Lab., XXV (1/4), 227-241, 1980.

(Article 15) 


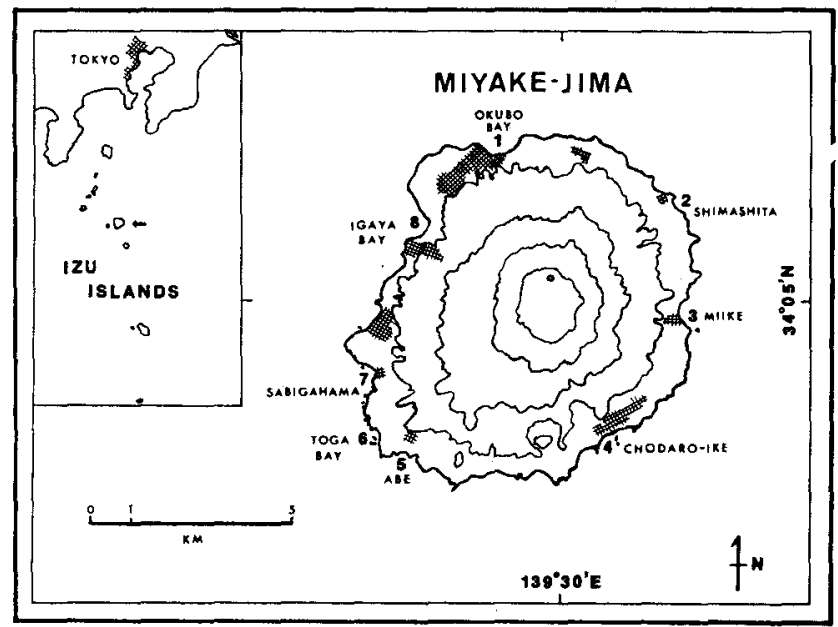

Fig. 1. The island of Miyake-jima, Japan, showing study areas.

Moyer and Shepard, 1975; Bell, 1976; Moyer, 1976; Moyer and Bell, 1976; Moyer and Ida, 1976; Shepard and Randall, 1976; Meyer, 1977; Moyer, 1977; Shepard and Okamoto, 1977; Shepard and Meyer, 1978a,b).

This study and those which will follow in the series are the result of hundreds of hours of submarine observation and collection at Miyake-jima. We believe that the listings presented will prove to be a reasonably complete representation of the inshore fish fauna of the island, to a depth of $30 \mathrm{~m}$.

\section{Marine Environment and Representative Fish Species}

The undersea environment at Miyake-jima is characterized by a substrate of black volcanic rock with an impressively lush growth of more than 150 species of algae (Brawley, personal communication), with the Phaeophyta predominating on the western coast, i.e. Igaya Bay and Sabigahama (Fig. 1). Among the Rhodophyta present, a large Gelidium crop supplies the major fishery on the island, centering in the waters off the eastern coast of the island (Moyer, 1965). More specifically, the marine habitat may be divided into six classifications: 1) black volcanic sand and gravel, 2) volcanic rocks and rubble over sand, 3) large volcanic boulders, 4) lava plateaus, 5) lava cliffs, tunnels and arches, and 6) coral reef patches. Examples of the most stable and common fish species, those which survive even the coldest winters, are included for each habitat classification below. It should be noted that representation is not intended to be complete.

1. Black volcanic sand and gravel: This habitat is the most poorly represented, with a limited population consisting of Xyrichtys spp., Anago anago, and a few others. At night these areas are invaded by large schools of pemphrids, Priacanthus cruentatus, and Monocentrus japonicus. During their breeding season in May and June, aggregations of several thousand Alteres monoceros gather over the sand substrate in Igaya Bay. 
2. Volcanic rock and rubble: This habitat supports a heavy algal growth and provides excellent cover for Calotomus japonicus, Prionurus microlepidotus, Parupeneus pleurotaenia, Cheilodactylus zonatus, Thalassoma cupido, Stethojulis interrupta terina, Halichoeres melanochir, Cirrhilabrus temminckii, Choerodon azurio, Pseudolabrus japonicus, Pomacentrus coelestis, P. nagasakiensis, Eupomacentrus altus, Amphiprion clarkii, Apogon cyanosoma, A. doederleini, Synodus variegatus, Gymnothorax kidako, Muraena pardalis, Lactoria fornasini, and others.

3. Large volcanic boulders: Common fishes in this habitat include Kyphosus lembus, K. cinerascens, Girella melanichthys, G. mezina, Prionurus microlepidotus, Calotomus japonicus, Cheilodactylus zonatus, Eupomacentrus altus, Centropyge interruptus, Chaetodon auripes, Parupeneus pleurotaenia, Chilomycterus affinis, Thalassoma cupido, Stethojulis maculata, Pomacentrus nagasakiensis, Chromis flavomaculata, Gymnothorax kidako, Muraena pardalis, and others.

4. Lava plateaus: A low diversity of fishes is found in this habitat. Representative fishes include Thalassoma cupido, Pseudolabrus japonicus, Calotomus japonicus, Prionurus microlepidotus, Cheilodactylus zonatus, Chaetodon auripes, and Pomacentrus coelestis.

5. Volcanic cliffs, tunnels and arches: This is perhaps the richest fish habitat at Miyake-jima. Included among the common representative species are Anthias nobilis, Chromis flavomaculata, C. chrysura. C. miyakeensis, C. weberi, C. margaritifer, C. albomaculata, Centropyge interruptus, Chaetodon nippon, Cheilodactylus zebra, Autoslomus chinensis, Epinephalus fasciatus, Apogon cyanosoma, A. doederleini, A. notatus, Prionurus microlepidotus, Naso lopezi, Caesio diagrammus, Labracoglossa argentiventris, Pomacentrus coelestis, P. nagasakiensis, Eupomacentrus altus, Pterois volitans, Sebasticus marmoratus, Adioryx ittodai, Brotula multibarbata, Gymnothorax kidako, Muraena pardalis and many others.

6. Coral reef patches: This habitat supports a limited fauna compared to a similar substrate at more tropical latitudes. This is undoubtedly due to the limited species composition among corals at Miyake-jima. Representative fishes include Thalassoma lutescens, Adioryx ittodai, Apogon cyanosoma, Chaetodon auripes, Eupomacentrus altus, Coris aygula, Anampses caeruleopunctatus, Chaeilodactylus zebra and others.

\section{Zoogeography}

It is of interest to compare the fish fauna of Miyake-jima, at the northern limits of the tropical Indo-Pacific, with that of a similar geographic location at the southern extremity of this vast oceanographic province. Lord Howe Island (31 32 'S, $\left.159^{\circ} 04^{\prime} \mathrm{E}\right)$, situated $630 \mathrm{~km}$ east of New South Wales, Australia, provides such a location. The fish fauna of Lord Howe Island has been studied in detail by Allen et al. (1976). Table 1 compares the total number of species per family of the four families investigated thus far at Miyake-jima with the same families from Lord Howe Island.

Although Miyake-jima lies at a somewhat higher latitude than Lord Howe, the Japanese island supports a more diverse fish fauna in three of the four families under comparison. The powerful flow of the Kuroshio Current past Miyake-jima from the Philippines at the northern edge of the extremely rich Indo-Malaysian region, un- 
Table 1. Comparison of numbers of species in four families of fishes at Miyake-jima, Japan and Lord Howe Island, Australia. (Lord Howe data from Allen et al., 1976)

\begin{tabular}{ccc}
\hline \multirow{2}{*}{ Family } & \multicolumn{2}{c}{ Number of species } \\
& Miyake-jima & Lord Howe Island \\
\hline Apogonidae* & 18 & 9 \\
Pomacentridae & 33 & 26 \\
Chaetodontidae & 22 & 22 \\
Pomacanthidae & 11 & 7 \\
Total & 84 & 64 \\
\hline
\end{tabular}

* Fourteen apogonids were recorded by Ida and Moyer (1974). Subsequent collections have yielded four additional species: Archamia fucata, Cheilodipterus macrodon, and two species of Apogon.

doubtedly accounts for a high recruitment potential for the vast majority of tropical species from that region and the Ryukyu Islands to the north.

Establishment of a particular species, even for a short period of time, is of course dependent upon the availability of suitable habitat. The near absence of obligative polyp-feeding chaetodontids (see Reese, 1977) and pomacentrids is almost certainly a result of the relatively low diversity and coverage of corals at Miyake-jima. However, for most of the remaining species at the island adequate food supply seems to offer no great obstacle. Apogonids and the majority of Miyake-jima pomacentrids are carnivores and/or planktivores. The remaining pomacentrids, and seven of eleven species of pomacanthids (i.e. Centropyge spp.) feed primarily on algae (Hiatt and Strasburg, 1960 ; 1960; Hobson, 1974; personal observation). The eroded volcanic substrate, with boulders, rock and rubble, and fractured cliffs with cracks, fissures and caverns, provides ideal cover for apogonids, pomacentrids and pomacanthids.

Great fluctuations in water temperature between winter and summer, with extremes from $13^{\circ}$ to $29.5^{\circ} \mathrm{C}$, may cause noticeable changes in the fish fauna of the island. Seemingly established, resident species in a given year or period of years may be very rare or totally lacking in another year. For example, Apogon apogonides appeared to be established in 1973 (Ida and Moyer, 1974), but was very rare in 1977. Recruitment from the plankton at Miyake-jima during the warm months shows interesting variations in species composition from year to year, apparently resulting from the meandering nature of the Kuroshio.

Whether the disappearance of certain marginal species from Miyake-jima's waters during particularly cold winters result solely from a low tolerance to cold water, to the disappearance of critical food supplies, or a combination of these and other factors remains to be investigated. Brawley (personal communication) reports a dramatic change in algal composition between winter and summer, and Dunn (personal communication) attributes winter color changes from greenish brown to white in the sea anemone Stoichactes haddoni to the disappearance of symbiotic zooxanthellae during the period of cold water, from January to early April. Similar examples are undoubtedly 


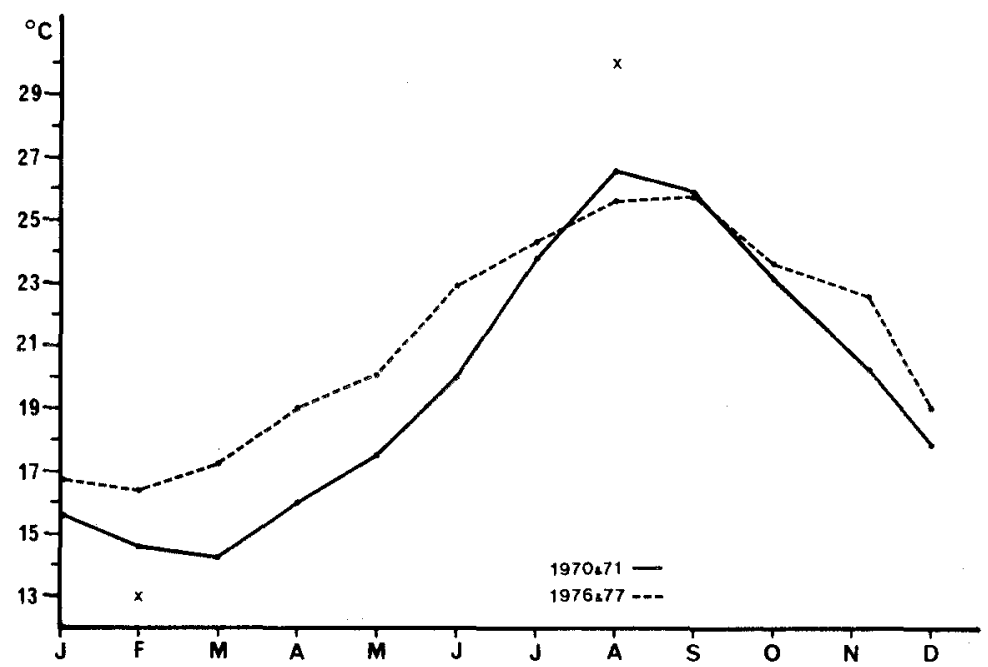

Fig. 2. Average monthly sea surface temperatures at Miyake-jima, Japan. $\mathrm{X}=$ temperature extremes recorded at $15 \mathrm{~m}$ depth oy divers.

quite common, and may play a major role in the depletion of certain species and individuals during cold months.

A warming trend in recent years (Fig. 2) has resulted in a great increase both in variety and density of tropical species at Miyake-jima. One apparent result of this trend is the sudden occurence in 1978 of great numbers of Acanthaster planci, which may be threatening Miyake-jima's limited coral populations (Moyer, 1978).

Unstable temperatures, with cycles of several years of warm winter periods followed by many cold winters provide strong selective pressures which may account for a number of southern Japanese endemics such as Stethojulis maculata, Chromis albomaculata and Pomacentrus nagasakiensis.

\section{Methods of Presentation}

In the species accounts below, selected information on the relative abundance, habitat preference, and ability to tolerate the low water temperatures occurring at Miyake-jima is presented. A species was considered established if a significant number of individuals was observed throughout the year, for several consecutive years. In certain cases, comments on nomenclatural usage, coloration in life, and miscellaneous observations on the biology of the species are included. Following each account, a list of site numbers, corresponding to Fig. 1, provides the localities at which the species has been observed. Unless otherwise noted, each species is represented by one or more specimens in the fish collection at the Tatsuo Tanaka Memorial Biological Station, Miyake-jima (TMBS). 


\section{Species Accounts}

\section{POMACENTRIDAE}

\section{Amphiprion clarkii (Bennett)}

Common and established. The biology of this species has been studied in detail at Miyake-jima (see Moyer and Sawyers, 1973; Bell, 1976; Moyer and Bell, 1976; Moyer, 1976; Moyer and Nakazono, 1978b). Sites 1-8.

Chromis albomaculata Kamohara

Established, common in certain areas. Found associated with volcanic cliffs, tunnels and arches, usually in depths greater than $20 \mathrm{~m}$. Sites 5, 6, 7, 8.

Chromis analis (Cuvier)

Established and common in depths below $25 \mathrm{~m}$. Habitat similar to that of $C$. albomaculata. Egg-tending adults have been observed in Igaya Bay and Sabigahama. Sites $5,7,8$.

\section{Chromis atripes Fowler and Bean}

Not common, but occasionally reaches adult size and spawns after warm winters. Sites $5,7,8$.

Chromis chrysura (Bliss)

(Plate I, B)

Established and common. Regularly reaches adult size and spawns at several localities around the island. Found in cliff, arch and tunnel habitats. Sites 1, 2, 3, $5,6,7,8$.

\section{Chromis flavomaculata Kamohara}

Established and common, abundant in some areas. Spawns anually. C. kennensis Whitley is a junior synonym. Sites $1,2,3,5,6,7,8$.

\section{Chromis lepidolepis Bleeker}

Not established or common, but small aggregations of juveniles appear during summer. Mortality due to cold temperatures is high, but some adults survive warm winters. Usually found in loose association with coral outcroppings. Sites 1, 6, 7, 8 .

\section{Chromis margaritifer Fowler}

Common and established, found in volcanic cliff and eroded lava flow habitats. Some mortality occurs during very cold winters. Sites $1,2,3,5,6,7,8$.

Chromis miyakeensis Moyer and Ida

Established, common to abundant in certain cliff, tunnel and arch habitats. Spawns anually. This species was described recently from Miyake-jima (Moyer and Ida, 1976). Sites 6, 7, 8 .

Apparently established; adults rare, but are observed regularly at depths greater 
than $25 \mathrm{~m}$. Originally described from the Ryukyu Islands, this species was previously known in the literature only from the holotype. Color in life pale brown, snout yellow, caudal fin and peduncle white. Sites 5, 8 .

Chromis vanderbilti (Fowler)

Rare, but occurs regularly. Reaches adult size after warm winters. Often found in association with tabular Acropora colonies in Toga Bay and Igaya Bay. Some mortality occurs due to low temperatures. Sites $1,6,7,8$.

Chromis weberi Fowler and Bean

Established; large aggregations of juveniles appear during summer, but winter kill is high. Some adults survive and spawn anually. Sites 1, 5, 6, 7, 8 .

Chromis xanthura (Bleeker)

Rare, apparently not established. A small number of adults have been observed; juveniles are usually found associated with small coral outcroppings on eroded lava flows. The identification of our material from Miyake-jima must remain tentative until studies of related forms elsewhere in the Indo-Pacific have been completed. Site 8.

Chromis species 1

(Plate I, D)

Not uncommon, but susceptible to low temperatures. Small aggregations occur occasionally during summer and fall in Igaya Bay. This and the following species will be treated in detail in a forthcoming review of Japanese Chromis by J. E. Randall, H. Ida, and J. T. Moyer. Color in life brown, a white spot at rear base of dorsal fin, lobes of caudal fin black. Site 8 .

Chromis species 2

(Plate I, E)

Established, but rare. This species is presently undescribed. Color in life dark brown, caudal fin and peduncle white. Sites 5,8 .

Dascyllus reticulatus (Richardson)

Not common or established. Adults rare, only small numbers survive warm winters. Usually found in association with small coral outcroppings in Igaya Bay. Site 8.

Dascyllus trimaculatus (Rüppell)

Established. Has become common due to several years of warm winters; some mortality occurs during cold winters. Spawns regularly during summer and early fall. Usually associated with anemone colonies on lava substrate, but may occasionally be found in small groups around boulders in areas where anemones are absent. Sites 1-8.

Abudefduf notatus (Day)

Not established. Juveniles not uncommon in tide pools, but rarely reach adult size. Sites $4,5,6,7,8$.

Abudefduf sexfasciatus (Lacépede)

Rare, not established. Adults are occasionally observed in the Chodaro-like tide 
pool, but no specimens have been collected. Prefers shallow, protected waters near shore. We follow most previous authors in considering $A$. coelestinus (Cuvier) a junior synonym of this species (see Allen et al., 1978). Sites 3, 4, 6, 7 .

Abudefduf sordidus (Forsskål)

Not established. Juveniles are not uncommon in tide pools, but adults have not been observed. Sites $4,5,6,7,8$.

Abudefduf vaigiensis (Quoy and Gaimard)

Common and established. Found in areas exposed to the open sea over bare substrate, also near piers and other man-made structures. Spawns during summer and fall. We recognize the Indo-Pacific $A$. vaigiensis as distinct from $A$. saxatilis (Linnaeus), a similar Atlantic form (see Hensley and Allen, 1977). Sites 1-8.

Eupomacentrus altus Okada and Ikeda

(Plate I, F)

Ubiquitous and extremely successful at Miyake-jima from depths of $2 \mathrm{~m}$ to at least $20 \mathrm{~m}$. Spawns during summer. Inhabits cliff, arch, rubble, boulder and coral patch habitats. Closely related to the widespread E. fasciolatus (Ogilby). Site 1-8.

Glyphidodontops glaucus (Cuvier)

Rare, not established. Small juveniles occasionally found in tide pools during summer and fall. Rarely, if ever, reaches adult size. Sites 4, 7, 8 .

Glyphidodontops leucopomus (Lesson)

Not common, but appears regularly and reaches adult size. Usually found in tide pools and shallow, protected waters near shore. Both the amabilis and leucopomus color forms have been observed (see Allen, 1975). Sites 4, 6, 7, 8.

Glyphidodontops rex (Snyder)

Rare, not established. Juveniles inhabit shallow tide pools in Igaya Bay; adults have not been observed. Sites $4,7,8$.

Glyphidodontops starcki (Allen)

Established, common in depths greater than $20 \mathrm{~m}$, although specimens have been taken as shallow as $7 \mathrm{~m}$. Found along edges of eroded lava flows, coral ridges bordered by sand or pebbled channels (Ida and Moyer, 1975). Sites 7, 8.

Plectroglyphidodon dickii (Liénard)

Established, not uncommon in certain areas where coral predominates. Adults are found regularly, associated with large tabular colonies of Acropora in Toga Bay. Some mortality occurs during winter. Sites 4, 6, 8 .

\section{Plectroglyphidodon leucozona (Bleeker)}

Not common, but established. Usually found in depths less than $3 \mathrm{~m}$. Spawning has been observed in the Chodaro-ike tide pool; eggs were deposited on the side of a large boulder and defended vigorously by the male parent. Some mortality occurs during very cold winters. Sites $4,6,7$. 
Pomacentrus bankanensis Bleeker

Rare, not established. Juveniles and occasional adults are found in rubble and boulder habitats at depths of 3 to $10 \mathrm{~m}$. Rarely suvives cold winters. Site 8 .

Pomacentrus coelestis Jordan and Starks

Common and established. Usually found in aggregations over rock rubble. Spawns during summer. Sites 1-8.

Pomacentrus nagasakiensis Tanaka

Common and established. Forms large aggregates of up to about 30 members, usually in areas of volcanic rock rubble. Moyer and Ida (1975) recently redescribed the species, and Moyer (1975) documented its reproductive behavior. Sites 1, 2, 3, $6,7,8$.

Pomacentrus vaiuli Jordan and Seale

(Plate I, G)

Rare, but established. Juveniles and small adults are occasionally seen in areas of rock rubble ranging in depth from 3 to at least $20 \mathrm{~m}$. We are unable to find any previous record of this species from Japanese waters, though it is rather common in some parts of the Ryukyu Islands. Sites 7, 8.

Pomachromis richardsoni (Snyder)

(Plate I, H)

Rare, not established. Small aggregations have been observed over coral outcroppings in Igaya Bay during summer. Sites 6, 8.

\section{CHAETODONTIDAE}

Chaetodon argentatus Smith and Radcliffe

Established, not uncommon in certain areas. Inhabits eroded lava flows and volcanic cliffs. Appears to suffer little temperature-related mortality. Sites 1, 2, 3, 5, 6, 7,8 .

\section{Chaetodon auriga Forsskål}

Not established. Juveniles common in late summer and fall, usually found in tide pools or shallow waters near shore. Occasional adults have been observed in depths to $18 \mathrm{~m}$. Sites $4,6,8$.

\section{Chaetodon citrinellus Cuvier}

Appears regularly in deep tide pools and shallow waters, but is not established. Small adults are occasionally observed. Susceptible to cold temperatures. Sites $4,6,7,8$.

\section{Chaetodon auripes Jordan and Snyder}

Most common member of the genus at Miyake-jima. Abundant in most areas, from tide pools to depths of at least $30 \mathrm{~m}$. Often forms large aggregations at dusk, possibly related to feeding or reproductive activity. This species has been commonly confused with $C$. collare Bloch (Burgess, 1978). Sites 1-8. 
Chaetodon daedalma Jordan and Fowler

Established, not common. Usually found in pairs at Miyake-jima, but forms aggregations in localities where the species is more common. Sites $1,6,7,8$.

\section{Chaetodon guentheri Ahl}

Rare, not established. Juveniles appear occasionally in tide pools; adults have been observed following warm winters. We recognize this wide-ranging species as distinct from the Hawaiian endemic C. miliaris Quoy and Gaimard. Sites 4, 6.

\section{Chaetodon kleinii Bloch}

Established, but uncommon. Some mortality occurs during cold winters. Found in areas of rock rubble and on eroded lava flows. Sites 1, 6, 7, 8 .

\section{Chaetodon lineolatus Cuvier}

Rare, probably not established. No specimens collected; included here on the basis of a single large adult $(>200 \mathrm{~mm} \mathrm{SL})$ sighted and photographed over large volcanic boulders in 1978 . Site 7 .

Chaetodon lunula (Lacépede)

Established, but not highly resistant to cold temperatures. Juveniles are common in tide pools during summer and early fall. Adults are observed regularly, but are somewhat rare. Sites 4, 5, 6, 8 .

\section{Chaetodon nippon Döderlein}

Established, common throughout the year. Second only to C. auripes in abundance among chaetodontids at Miyake-jima. Often forms large aggregations. Found in areas of rock rubble, cliffs and eroded lava flows, in depths of 5 to at least $30 \mathrm{~m}$. Sites $1,2,3,5,6,7,8$.

\section{Chaetodon ornatissimus Cuvier}

Rare, not established. One juvenile taken at a depth of $7 \mathrm{~m}$ from the vicinity of large tabular Acropora colonies. Site 6.

\section{Chaetodon punctatofasciatus Cuvier}

Rare, not established. Occasionally observed in depths from 10 to $20 \mathrm{~m}$, usually in association with Acropora colonies. Site 8.

\section{Chaetodon speculum Cuvier}

Rare, not established. No specimens collected; adults have been observed only on two occasions. Site 6 .

\section{Chaetodon unimaculatus Bloch}

Rare, not established. Juveniles appear regularly during summer, occasionally surviving winter and reaching adult size. Sites 1, 6, 8 .

\section{Chaetodon vagabundus Linnaeus}

Rare, not established. Juveniles occur in tide pools. Small adults have been observed following warm winters. Sites $4,7,8$. 
Chaetodon xanthurus Bleeker

(Plate II, A)

Rare, not established. Adults are occasionally observed in Igaya Bay. The closely related $C$. mertensii Guvier has not been found at Miyake-jima. We follow Burgess (1978) in our identification of this species. Site 8.

Coradion altivelis McCulloch

(Plate II, B)

Rare, but established. Large adults are found in depths greater than $15 \mathrm{~m}$ off Sabigahama. Usually associated with volcanic cliffs, arches and tunnels. We follow Burgess (1978) in identifying our material as C. altivelis, but the relationship of this species and $C$. fulvocinctus Tanaka merits further investigation (see Yasuda and Zama, 1975). Sites 7, 8.

Forcipiger flavissimus Jordan and McGregor

Established, rather common for the genus. Found in a wide variety of habitats, from rock rubble to cliffs, in depths ranging from 8 to at least $25 \mathrm{~m}$. Some mortality may occur during cold winters. Sites $1,2,5,6,7,8$.

Hemitaurichthys polylepis (Bleeker)

Rare, no specimens collected. Adults have been observed only in depths greater than $20 \mathrm{~m}$. The status of this species at Miyake-jima is uncertain. Sites 6,8.

Heniochus acuminatus (Linnaeus)

Established, but uncommon. Adults are usually observed in pairs. Our limited material includes only $H$. acuminatus, but the similarly-patterned $H$. diphreutes Jordan may also be present at Miyake-jima (see Allen and Kuiter, 1978). Sites 5, 7, 8.

Heniochus varius (Cuvier)

Very rare, no specimens collected. Included here on the basis of sight records in Igaya Bay. Site 8.

Megaprotodon trifascialis (Quoy and Gaimard)

Not uncommon in coral-rich areas in Toga Bay and Igaya Bay. Regularly reaches adult size, but is susceptible to cold winters. Sites 6,8 .

\section{POMACANTHIDAE}

Centropyge bicolor (Bloch)

Rare, not established. Occasional juveniles and adults are observed on eroded lava flows with some coral cover. Appears vulnerable to cold temperatures. Site 8. Centropyge bispinosus (Günther)

(Plate II, C)

Very rare, not established. One adult female collected in $19 \mathrm{~m}$ in 1976; in 1978 another individual of this species was often observed feeding with a harem of C. tibicen. Site 8 .

Centropyge ferrugatus Randall and Burgess

Very rare, not established. One juvenile taken in Igaya Bay in 1976; few adults 
have been observed. Site 8 .

Centropyge interruptus (Tanaka)

Established, very common; the most successful angelfish at Miyake-jima. Usually found in cliff, tunnel, and eroded lava flow habitats. Spawns daily at dusk during summer. Moyer and Nakazono (1978a) have demonstrated sex inversion in this species, and described its reproductive behavior. Sites 1, 2, 3, 5, 6, 7, 8 .

Centropyge shepardi Randall and Yasuda

Very rare, not established. No specimens have been collected. A single individual about $50 \mathrm{~mm}$ in total length was photographed along an eroded lava flow in $26 \mathrm{~m}$ during September of 1979 . Site 8.

Centropyge tibicen (Cuvier)

Established, but uncommon. Juveniles appear regularly during summer, but adults are rare. Spawning has been observed in Igaya Bay. Population stucture described by Moyer and Nakazono (1978a). Some mortality occurs during winter, apparently due to cold temperatures. Found in rock rubble and eroded lava flow habitats. Adults at Miyake-jima are always loosely associated with Acropora corals. Site 8 .

\section{Centropyge vrolikii (Bleeker)}

Established, but uncommon. Adults are observed occasionally, but are somewhat susceptible to low temperatures. Population structure described by Moyer and Nakazono (1978a). Habitat similar to that of C. tibicen. Site 8.

Genicanthus semifasciatus Kamohara

Established, common along volcanic cliffs and lava flows in depths greater than $35 \mathrm{~m}$. Sites 7,8 .

Holocanthus venustus Yasuda and Tominaga

(Plate II, D)

Very rare, apparently not established. One specimen collected in 1976 from fissures in a large submarine tunnel off Abe at a depth of $17 \mathrm{~m}$. Site 5 .

Pomacanthus semicirculatus (Cuvier)

Established, but adults are rare. Juveniles are found in deep tide pools and shallow, protected waters near shore. Sites 2, 4, 6, 7, 8.

Pomacanthus imperator (Bloch).

Rare, but established. Adults of this species are observed more frequently than those of $P$. semicirculatus at Miyake-jima. Juveniles are found in deep tide pools. Sites $5,6,7,8$.

\section{Acknowledgments}

Many scientists contributed to this study during their stays at TMBS. Among them, special appreciation is due to Dr. Hitoshi Ida (Kitasato University), Dr. John E. 
Randall (Bernice P. Bishop Museum), Dr. Gerald R. Allen (Western Australian Museum), Prof. Lev Fishelson (Tel Aviv University), and Mr. Scott Dolginow (Colgate University) for assistance in collection of specimens and useful advice. Dr. Daphne F. Dunn (California Academy of Sciences) and Dr. Susan Brawley (National Museum of Natural History) investigated invertebrates and marine algae respectively during their 1976-1977 studies at TMBS. We are indebted to both of them for adding to our knowledge of the flora and fauna of Miyake-jima waters. Thanks are due to Dr. Steven S. Amesbury and Dr. Lucius G. Eldredge of the University of Guam Marine Laboratory for reading the manuscript and making suggestions for its improvement. Finally, we especially want to thank Katherine A. Meyer of TMBS for considerable help in collecting and curating specimens, sharing observations, and for continuous support.

\section{REFERENCES}

Allen, G.R. 1975. Damselfishes of the south seas. 240 pp. T.F.H. Publications Inc., Neptune City, N.J.

,M. Bauchot and M. Desoutter, 1978. The status of Abudefduf sexfasciatus (Lacepede), a pomacentrid fish from the Indo-West Pacific. Copeia, 1978(2), pp. 328-330.

and P.C. Heemstra, 1976. Cheilodactylus rubrolabiatus, a new species of morwog (Pisces: Cheilodactylidae) from Western Australia, with a key to the cheilodactylid fishes of Australia. Rec. West Aust. Mus., 4(4), pp. 311-325.

and R.H. Kuiter, 1978. Heniochus diphreutes Jordan, a valid species of butterflyfish (Chaetodontidae) from the Indo-West Pacific. J. Royal Soc. West. Aust., 61(1), pp. 11-18.

__- , D.F. Hoese, J.R. Paxton, J.E. Randall, B.C. Russell, W.A. Starck II, F.H. Talbot and G.P. Whitley, 1976. Annotated checklist of the fishes of Lord Howe Island. Rec. Aust. Mus., 30(15), pp. 365-454.

Bell, L.J., 1976. Notes on the nesting success and fecundity of the anemonefish Amphiprion clarkii at Miyake-jima, Japan. Japan. J. Ichthyol., 22(4), pp. 207-211.

Burgess, W.E. 1978. Butterflyfishes of the world. 832 pp. T.F.H. Publications Inc., Neptune City, N.J.

Hensley, D.A. and G.R. Allen, 1977. A new species of Abudefduf (Pisces: Pomacentridac) from the IndoAustralian Archipelago. Rec. West. Aust. Mus., 6(1), pp. 107-118.

Hobson, E.S. 1974. Feeding relationships of teleostean fishes on coral reefs in Kona, Hawaii. Fishery Bull., 72(4), pp. 915-1031.

Honda, M., Y. Nozu and Y. Suzuki, 1958. Miyake-jima Mikura-jima shokubutsu chosa hokoku. In: Izu Shoto bunka-sai sogo chosa hokoku, I, pp. 11-37. (published in Japanese by the Tokyo Metropolitan Government).

Hiatt, R.W. and D.W. Strasburg, 1960. Ecological relationships of the fish fauna on the coral reefs of the Marshall Islands. Ecol. Monogr., 30, pp. 65-127.

Ida, H. and J.T. Moyer, 1974. Apogonid fishes of Miyake-jima and Ishigaki-jima, Japan, with description of a new species. Japan J. Ichthyol., 21(3); pp. 113-128.

- 1975 . Range extention of the damselfish Abudefduf starcki from the Coral Sea to Japan. Japan. J. Ichthyol., 22(2), pp. 109-111.

Kurata, Y. and M. Nakagawa, 1962. Miyake-jima suisan kaihastu jigyo hokoku (II). Miyake-jima no gyoruiso to gyokakuryo. Tosuishi Chosa Kenkyu Yoho (30), pp. 21-31. (in Japanese)

Meyer, K.A., 1977. Reproductive behavior and patterns of sexuality in the Japanese labrid fish Thalassoma cupido. Japan. J. Ichthyol., 24(2), pp. 101-112.

Moyer, J.T. 1957. The birds of Miyake-jima, Japan. Auk, 74, pp. 214-228.

1965. Bounty of the Kuroshio: a study of an Izu Island fishing settlement. In: Beardsley, 
R.K., Ed., Studies in Japanese culture: I. Univ. Michigan Press, pp. 106-138.

- 1975. Reproductive behavior of the damselfish Pomacentrus nagasakiensis at Miyalse-jima, Japan. Japan. J. Ichthyol., 22(3), pp. 151-163.

1976. Geographical variation and social dominance in Japanese populations of the anemonefish Amphiprion clarkii. Japan. J. Ichthyol., 23(1), pp. 12-22.

- 1977. Aggressive mimicry between juveniles of the snapper Lutjanus bohar and species of the damselfish genus Chromis from Japan. Japan. J. Ichthyol., 24(3), pp. 218-222.

1978. Crown of thorns starfish invades Miyake-jima. Marine Park J., (44), p. 17. (in Japanese)

and H. Ida, 1975. Redescription of Pomacentrus nagasakiensis and comparison with specimens from Miyake-jima and the Bonin Islands. Japan. J. Ichthyol., 22(2), pp. 104-108.

and 1976. Description of a new species of damselfish, Chromis miyakeensis from Miyake Island, Japan. Japan. J. Ichthyol., 22(4), pp. 189-194.

- and A. Nakazono, 1978a. Population structure, reproductive behavior and protogynous hermaphroditism in the angelfish Centropyge interruptus at Miyake-jima, Japan. Japan. J. Ichthyol., 25(1), pp. 25-39.

and 1978b. Protandrous hermaphroditism in six species of the anemonefish genus Amphiprion in Japan. Japan. J. Ichtyol., 25(2), pp. 101-106.

and C.E. Sawyers, 1973. Territorial behavior of the anemonefish Amphiprion xanthurus with notes on the life history. Japan. J. Ichthyol., 20(2), pp. 85-93.

- and J.W. Shepard, 1975. Notes on the spawning behavior of the wrasse Cirrhilabrus temminckii. Japan. J. Ichthyol., 22(1), pp. 40-42.

Reese, E.S., 1977. Coevolution of corals and coral feeding fishes of the family Chaetodontidae. Proc. Int. Coral Reef Symp., 3rd, pp. 267-274.

Shepard, J.W. and K.A. Meyer, 1978a: New records of labrid fishes from Japan. Uo, (29), pp. 31-40. - $1978 \mathrm{~b}$. A new species of the labrid fish genus Macropharyngodon from southern Japan. Japan. J. Ichthyol., 25(3), pp. 159-164.

and K. Okamoto, 1977. A record of the labrid fish Pseudocheilinus evanidus from Japan. Japan. J. Ichthyol., 23(4), pp. 233-236.

and J.E. Randall, 1976. Notes on the labrid fish Stethojulis maculata from Japan. Japan. J. Ichthyol., 23(3), pp. 165-170.

Tamura, T. (Editor), 1974. Miyake hoka ikasho kaichu-koen yotei-chiku gakujitsu chosa hokoku-sho. 136 pp., Tokyo Metropolitan Government. (in Japanese)

Yasuda, F. and A. Zama, 1975. Notes on the two rare chaetodont fishes, Parachaetodon ocellatus and Coradion chrysozonus, from the Ogasawara Islands. J. Tokyo Univ. Fish., 62(1), pp. 33-38. 


\section{EXPLANATION OF PLATES I-II}

Plate I. Pomacentrid fishes from Miyake-jima.
A) Chromis albomaculata, $65.0 \mathrm{~mm}$ SL.
B) Chromis chrysura, about $20 \mathrm{~mm}$ SL, showing juvenile color pattern.
C) Chromis ovatiformis, $40.5 \mathrm{~mm} \mathrm{SL}$.
D) Chromis species 1 , about $35 \mathrm{~mm} \mathrm{SL}$.
E) Chromis species 2, about $45 \mathrm{~mm}$ SL.
F) Eupomacentrus altus, about $20 \mathrm{~mm} \mathrm{SL}$, showing juvenile color pattern.
G) Pomacentrus vaiuli, about $45 \mathrm{~mm}$ SL.
H) Pomachromis richardsoni, about $35 \mathrm{~mm} \mathrm{SL}$.

Plate II. Chaetodontid and pomacanthid fishes from Miyake-jima.
A) Chaetodon xanthurus, $57.0 \mathrm{~mm}$ SL.
B) Coradion altivelis, $132.0 \mathrm{~mm}$ SL.
C) Centropyge bispinosus, $76.0 \mathrm{~mm} \mathrm{SL}$.
D) Holocanthus venustus, $68.0 \mathrm{~mm} \mathrm{SL}$. 


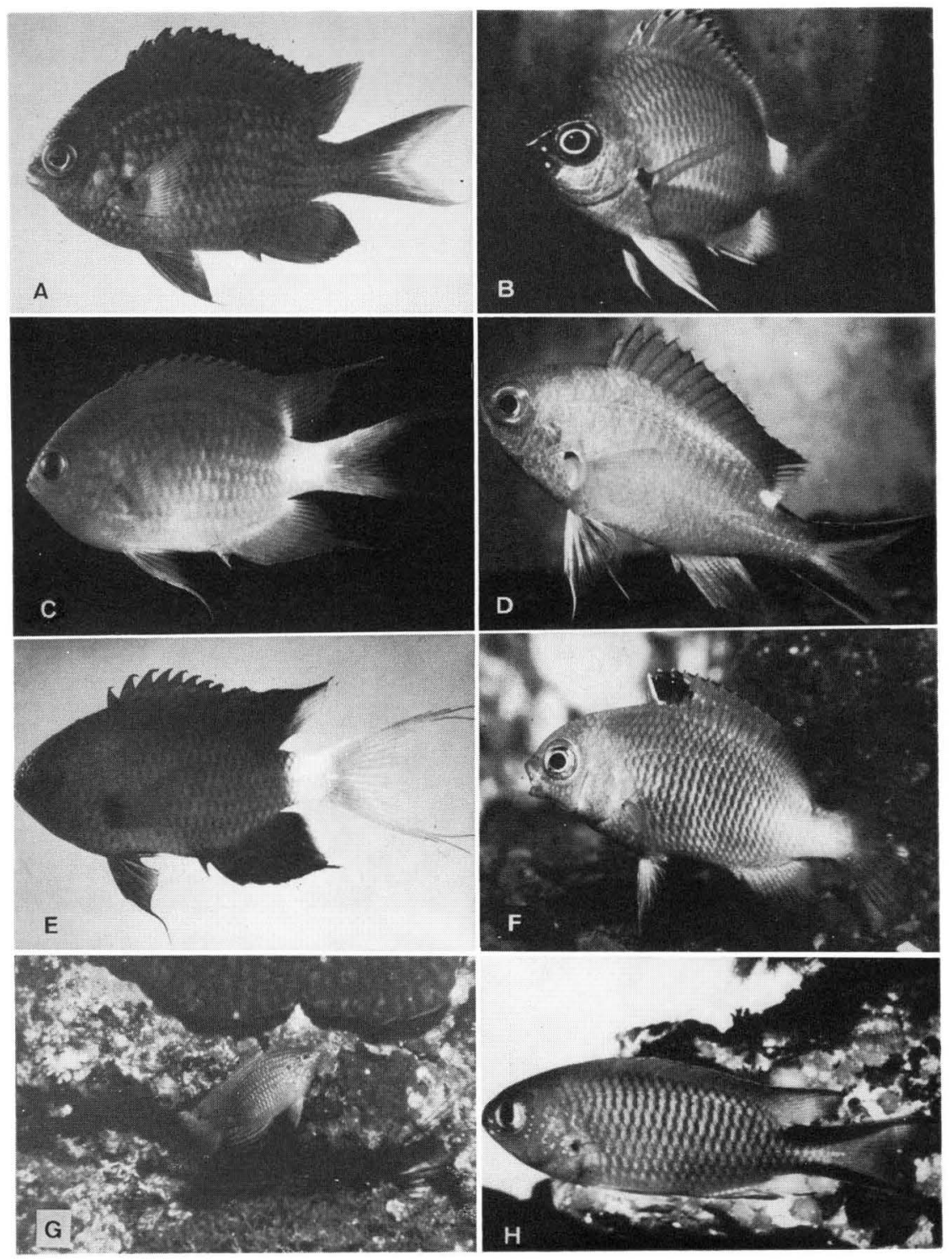

J. W. Shepard \& J. T. Moyer: Checklist of Miyake-jima Fishes 
Publ. Seto Mar. Biol. Lab., XXV (1/4), 1980.

Plate II

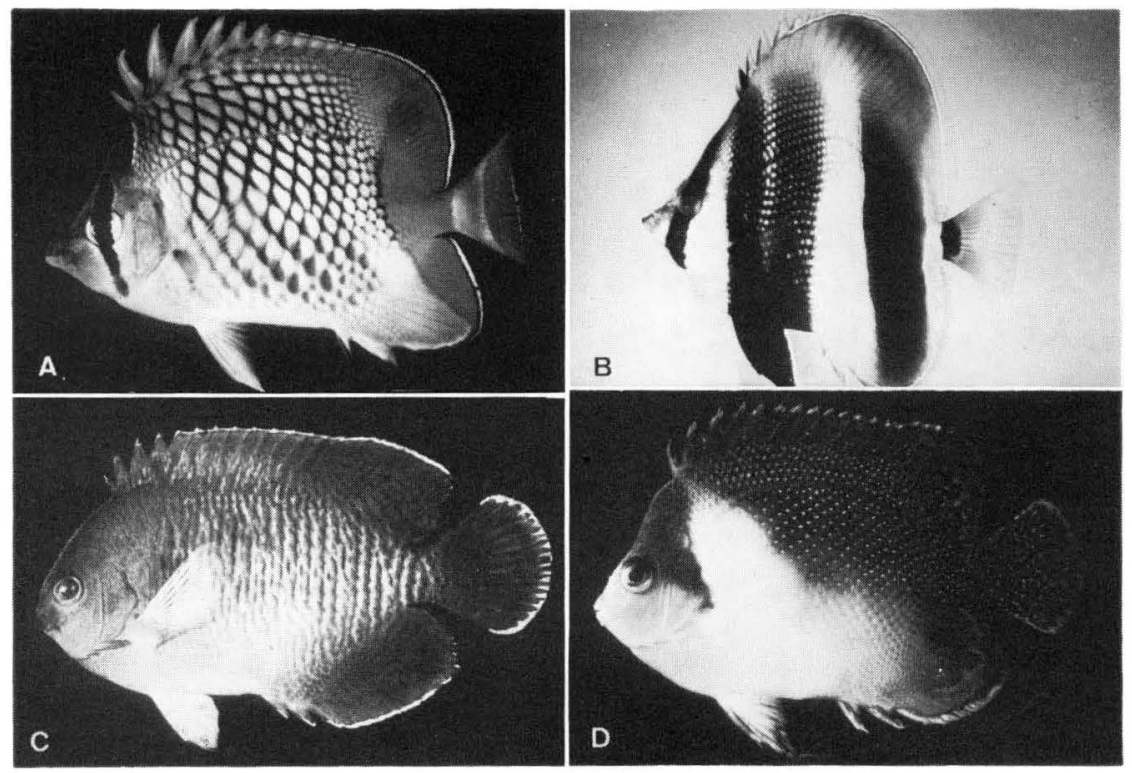

J. W. Shepard \& J. T. Moyer: Checklist of Miyake-jima Fishes 